\title{
THE PREVENTIVE CONTROL OF WHITE ROOT ROT DISEASE IN SMALL HOLDER RUBBER PLANTATION USING BOTANICAL, BIOLOGICAL AND CHEMICAL AGENTS
}

\author{
Joko Prasetyo \& Titik Nur Aeny \\ Department of Agrotechnology (Plant Protection Division) \\ University of Lampung, Bandar Lampung \\ E-mail:jkdwiprasetyo21@gmail.com
}

\begin{abstract}
The preventive control of white root rot disease in small holder plantation using botanical, biological, and chemical agents. A field and laboratory experiment were conducted from June 2008 to December 2009 in Panumangan, Tulang Bawang - Lampung. The field experiment was intended to evaluate the effect of botanical plants (Alpinia galanga, Sansiviera auranthii, and Marantha arundinacea), biological agents (organic matter and Trichoderma spp.), and chemical agents (lime and natural sulphur) on the incidence of white root rot disease and population of some soil microbes. The laboratory experiment was conducted to observe the mechanism of botanical agents in controlling white root rot disease. In the field experiment, the treatments were applied in the experimental plot with cassava plant infection as the indicator. The variables examined were the incidence of white root rot and population of soil microbes. In the laboratory experiment, culture of $R$. microporus was grown in PDA containing root exudate of the antagonistic plant (botanical agent). The variable examined was colony diameter of $R$. microporus growing in the PDA plates. The results of the field experiment showed that planting of the botanical agents, and application of Trichoderma spp., as well as natural sulphur, decreased the incidence of white root rot disease. The effectiveness of M. arundinacea and Trichoderma spp. was comparable to natural sulphur. The laboratory experiment showed only root exudate of A. galanga and S. auranthii that were significantly inhibit the growth of $R$. microporus.
\end{abstract}

Key words: white root rot, rubber, cassava, Alpinia galanga, Sansiviera auranthii, Marantha arundinacea, Trichoderma, organic matter, lime

\begin{abstract}
ABSTRAK
Pengendalian preventif penyakit akar putih di perkebunan rakyat menggunakan agensia botanis, biologis, dan kimiawi . Percobaan lapangan dan laboratorium telah dilakukan dari bulan juni 2008 sampai dengan bulan Desember 2009 di Panumangan, Lampung. Percobaan lapangan ditujukan untuk mengetahui pengaruh agensia botanis (Alpinia galanga, Sansiviera auranthii, and Marantha arundinacea), biologis ( bahan organik dan Trichoderma spp.), dan kimiawi (kapur dan belerang) terhadap penyakit akar putih dan populasi beberapa mikroba tanah. Percobaan laboratorium ditujukan untuk mengamati kemampuan tanaman antagonis dalam menekan penyakit akar putih. Pada percobaan lapangan bahan-bahan diaplikasikan pada plot percobaan dengan tanaman singkong sebagai indikator infeksi. Variabel yang diamati adalah insiden penyakit akar putih dan populasi mikroba. Pada percobaan laboratorium, kultur $R$. microporus ditumbuhkan pada media PDA yang mengandung eksudat tanaman antagonis; variabel yang diamati adalah diameter koloni $R$. microporus. Hasil percobaan lapangan menunjukkan bahwa tanaman antagonis dan Trichoderma secara nyata menekan insiden penyakit akar putih. Dari hasil percobaan di laboratorium diketahui bahwa hanya eksudat akar tanaman A. galanga dan S. auranthii yang secara nyata menghambat pertumbuhan R. microporus.
\end{abstract}

Kata kunci: Akar putih, karet, singkong, Alpinia galanga, Sansiviera auranthii, Marantha arundinacea, Trichoderma, bahan organis, dan kapur.

\section{INTRODUCTION}

White root rot disease (Rigidoporus microporus) is very serious disease in rubber plantation. The disease was reported as a serious threat since it causes significantly yield loss. The disease causes loss on production about $3-15 \%$ with the financial value about
2.1 billion rupiahs every year particularly in small holder plantation. The damage in small holder plantation occurred often in the areas where stumps of rubber and primary forest trees exist, and in sandy and loose soil areas (Widjanarko, 1969; Basuki, 1981; Basuki, 1982; Situmorang \& Budiman, 1990). 
In small holder rubber plantations, control of white root rot disease is rarely conducted so that it caused high incidence of the disease in those areas. Some of the reasons were due to the lack of farmers' knowledge both on the disease and the the control methods, and the lack of farmer's income. Therefore it is necessary to introduce alternative control methods suitable to the social and economic condition of the rubber farmers.

In the control of white root rot disease, preventive efforts is much better than curative efforts such as using fungicides. The preventive controls of white root rot disease consist of the elimination of infection sources and crop protection. The most effective infection source elimination recomended untill now is by throwing of the stumps mechanically and the elimination of the roots residu from the plantation areas (Fox, 1977; Liyanage et al., 1984). However, this is is difficult to be applied by rubber small holders because of the high cost. Other method of stumps eliminatain suitable to the farmers is the use of some chemicals to poison old stumps (Fox, 1977; Basuki, 1981), burning of old stumps, growing of antagonistic plants (Martin \& du Plessix 1969; Situmorang \& Suryaningtyas, 2003), and the use of decomposer fungi (Situmorang, 1996). The most effective protection is the use of synthetic fungicides (Situmorang \& Budiman, 1990; Situmorang, 1994a) but this method is expensive because of the high price of the synthetic fungicides. Other control methods cheaper than the use of synthetic fungicides and more suitable to small holder farmers are the use of natural sulphur (Azaldin, 1985; Basuki, 1986), application of Trichoderma spp. (Soepena et al., 1992; Situmorang, 1994b) and the use of botanical agents (antagonistic plant) (Situmorang \& Suryaningtyas, 2003). This study was conducted to evaluate the effects of botanical agents (Alpinia galanga, Sanseviera auranthii, and Marantha arundinacea), biological agents (organic matter and Trichoderma spp.), and chemical agents (natural sulphur and lime) on white root rot incidence and some soil microbes population; and to envestigate the role of botanical agents on white root rot incidence.

\section{MATERIALS AND METHODS}

Laboratory experiment was conducted in the Laboratory of Plant Disease, Faculty of Agriculture, University of Lampung from July to October, 2009. Plant root exudates were collected from each of the rhizosphere of the botanical agents tested. The PDA medium containing $300 \mathrm{ppm}$ of streptomycine was used to culture $R$. microporus. As much as $1 \mathrm{ml}$ of root exudate was spread on the surface of each petri plate.
The variable observed was diameter colony of $R$. microporus at three and six days after investation.

A field experiment was conducted in small holder rubber plantation in Penumangan Baru Village, Central Tulang Bawang District, Tulang Bawang regency, Lampung Province, from June 2008 to December 2009. This field experiment was intended to observe the effect of botanical agents, organic matters, Trichoderma spp., natural sulphur, and lime on the incidence of white root rot disease and some soil microbes population. This field experiment consisted of eight treatments arranged in randomized complete block design with three replicates. The treatments were three botanical agents (galangale, sansivera, and Marantha arundinacea) grown in the rubber field; Trichoderma spp., organic matter, and two chemical agents (natural sulphur and lime) applied in the rubber field, and a control. The Trichoderma spp. (approx. $10^{3}$ spores per gram rice brand) were obtained from Sembawa Rubber Research Center. The incidence of white root rot infection was observed on cassava cuttings that were planted in the experimental plots as the indicator plant. Three tested botanical agents were grown around the cassava cuttings. The biological agents (Trichoderma spp. and organic matters) were applied on the soil surface around cassava cuttings as much as 100 gram per cutting. Variables examined were white root rot incidence on the cassava cuttings and abundance of soil microbes including mycorrhiza, nematodes, and nonpathogenic soil fungi (fungi other than white root rot fungi). For the observation of soil microbes, composited soil samples as much as $1,0 \mathrm{~kg}$ were collected from each sampling point of each plot, within the depth of $0-20 \mathrm{~cm}$.

White Root Rot Incidence Observation. Within every experiment plot, the number of normal or healthy growing cassava cuttings and wilting cassava cuttings were counted. White root rot disease incidence were determined using the formula as follow:

$$
\mathrm{DI}=\frac{\mathrm{n}}{\mathrm{N}} \times 100 \%
$$

Where DI = white root rot disease incidence,

$\mathrm{n}=$ number of wilting cassava, and

$\mathrm{N}=$ number of total population of cassava plants per plot observed.

Mycorrhizal Fungi Observation. Extraction of mycorrhizal spores was conducted using sieving and decanting method. As much as $50 \mathrm{~g}$ soil was put in a plastic jar (2 L), added by $300 \mathrm{cc}$ tap water, and mixed thoroughly for several seconds to detach mycorrhizal 
spores (such as spores of Glomus manihotis) from the roots. Let the suspension in 1 minute to deposit the coarse particles before decanting using sieving tools with 250, 100 , and 38 um of pore diameter. During sieving, repeated washing were conducted using flowing water. The retained aliquot of the smallest sieving tool was placed in beaker glass using $100 \mathrm{cc}$ of flowing water. The aliquot was mixed with glass rod and placed in centrifuge tubes $(50 \mathrm{cc})$. As much as 25-30 cc of sugar dilution $(60 \% \mathrm{~b} / \mathrm{v})$ was placed in the base of the centrifuge tubes using plastic syringe. Centrifuge tubes were centrifuged with the speed of $2900-3000 \mathrm{rpm}$ in 2 minutes. Mycorrhizal spores were collected using 38 um sieving tool and washed with flowing water to free the spores from sugar. Using spraying bottle mycorrhizal spores were stored in grid line Petri dish for the population counting under stereoscopic microscope (40x). Spores with the same morphology were taken with micro pipette and grouped for the genus identification. Mycorrhizal spores were identified until the level of genus using the identification book on VAM fungi (Schenk \& Perez, 1990).

Nematode Observation. Nematode extraction on 300 cc of soil samples were conducted using varied level of sieving tools and then centrifused in sugar dilution (500 $\mathrm{g}$ in 11 solvent) according to Gafur \& Swibawa (2004). Laboratory proccess and the enumeration of abundance and diversity of soil nematodes is the same as explain in community survey of nematode in method of plant parasitic nematode management on the coffee base agricultural land.

Observation of Fungi other than $\boldsymbol{R}$. microporus. The observation of nonpathogenic fungi abundance was conducted using plate-counting methods. Soil sample was serial diluted and from each of dilution level $1 \mathrm{ml}$ was spread on media containing rose-bengal chloramphenicol. The observation was conducted by grouping, counting, and identifying fungal colony with the same morphology. Identification of fungi was conducted at genus level based on fungal morphology.

\section{RESULTS AND DISCUSSIONS}

The results of the field experiment showed that Sanseviera sp., A. galanga, Trichoderma spp., natural sulphur, and $M$. arundinacea significantly decreased the disease incidence of white root rot on cassava plants (Table 1). The results also showed that soil microbes population were affected by the treatments, and later they may affect the white root rot incidence.
Trichoderma spp. decreased soil fungi population (Figure1), but $M$. arundinacea increased soil fungi population. It is known that $M$. arundinacea tubers contain carbohydrates that act as the source energy for most soil fungi. In this experiment, the effectiveness of $M$. arundinacea in suppressing the incidence of white root rot is tend to be better than natural sulphur. Beside that, all treatments decreased the population of nematodes but did not affected the population of mycorrhizal fungi.

Trichoderma spp. was significantly decreased $(82 \%)$ the incidence of white root rot on the indicator plants. It is known that Trichoderma spp. are antagonist fungi against many pathogenic fungi (Monte, 2001). The work of Jayasuriya and Thenakoon (2007) showed that Trichoderma isolates obtained from rubber growing areas were antagonistic to $R$. microporus. The mechanism of Trichoderma spp. in controlling plant disease is very complex. Trichoderma spp. was widely reported as the best antagonist fungi since its ability in competition for nutrients and space, producing some enzymes and toxic substance or antibiotics, and also act as mycoparasite (Tahia et al., 2004).

Organic matter tended to decrease the white root rot incidence on cassava plants as the indicator plant. This result indicated that organic matter has many factors potentially suppressed the growth of $R$. microporus. Organic matter has a role as the food base of some soil microbes (Lewis \& Papavizas, 1984) that are being antagonist of $R$. microporus. Another possible reason why organic matter tended to decrease white root rot incidence is related to parasitic nematodes population. It is known that under the organic matter influence, the total number of nematode population significantly decreased compared to control (Figure1). As in many cases, nematodes have a role as agravator for plant disease, including white root rot. The decrease of total nematode population may due to the occurence of the pathogen of nematode, i.e. Arthrobotrys spp. Effects of organic matter was statistically not different. Organic matter was reported can supply high nitrogens, and this condition will increase the activity of laccase (D’Souza et al., 1999) resulted in the increase of wilt incidence.

Lime treatment was also tended to decrease $(32 \%)$ white root rot incidence. It indicated that lime affected the growth of $R$. microporus. The result of previous study showed that the increase of $\mathrm{pH}$ in acid soil promoted the population of antagonistic fungi against $R$. microporus, and finally suppressed the incidence of white root rot (Prasetyo et al., 2009). The white-root rot fungus prefers porous soil with netral $\mathrm{pH}$ (around 6- 
Table 1. The disease incidence of white root rot observed on cassava as the indicator plant

\begin{tabular}{lc}
\hline Treatments & White root rot incidence $(\%)$ \\
\hline Control & $18.7 \mathrm{a}$ \\
Lime & $12.7 \mathrm{ab}$ \\
Organic Matter & $10.0 \mathrm{abc}$ \\
Sanseviera sp. & $8.0 \mathrm{bc}$ \\
Alpinia galanga & $4.7 \mathrm{bc}$ \\
Trichoderma spp. & $3.3 \mathrm{bc}$ \\
Natural Sulphur & $2.7 \mathrm{bc}$ \\
Marantha arundinacea & $1.0 \mathrm{c}$ \\
\hline
\end{tabular}

Numbers in the column followed by the same letter are not significantly different according to LSD test at $\alpha=0.05$.

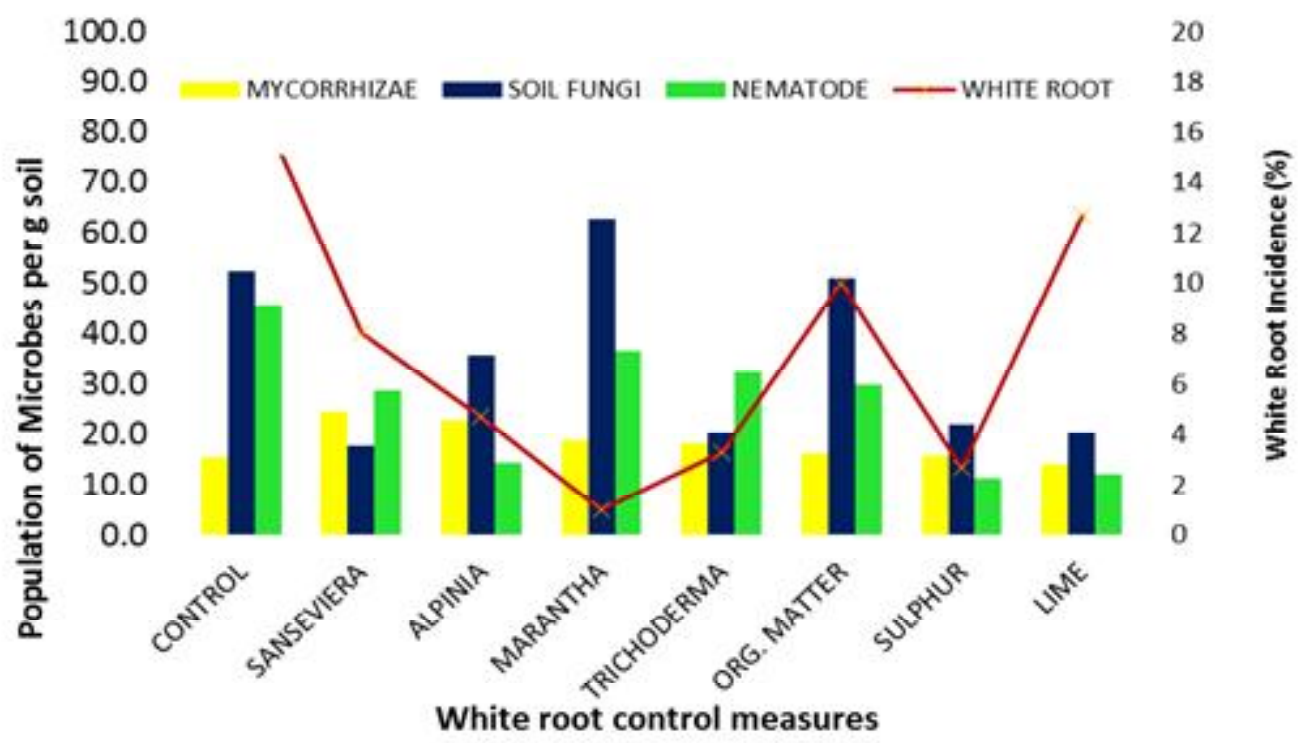

Figure 1. Effect of plant root exudates on white root rot incidence and ppopulation of soil microbs

7), including in liparite soil in East Sumatra and Soutern Mountains in East Java (Semangun, 2000). In South Sumatra this disease was commonly found in small holder rubber plantation grown in sandy soil (Situmorang and Budiman, 1990). This demonstration plots (acidic soil, $\mathrm{pH} 4$ - 4.04) showed that the increase in $\mathrm{pH}$ correlated with the decrease in the white-root disease incidence (Prasetyo et al., 2009). This correlation seemed to be indirect, possibly through the increase of soil fungi population and diversity.

Botanical agents such as $M$. arundinacea, A. galanga, and Sanseviera sp. significantly decreased the incidence of white root rot on cassava cuttings as the indicator plants in the field. The results of the laboratory study, also showed that root exudates of Marantha arundinacea, A. galanga and S. auranthii decreased the colony diameter of $R$. microporus (Table 2). It was known that $A$. galanga and Sanseviera sp. produce toxic substance and produce essensial oil that toxic to most of fungal taxon. Marziana (2008) reported that root exudates of those two plants effectively suppressed the in vitro growth of $R$. microporus.

In the field study, $M$. arundinacea was the most effective in decreasing the incidence of white root rot disease (Table 1, Figure 1). In the laboratory study, $M$. arundinacea did not significantly suppress the growth of $R$. microporus at three days after incubation but later on six days after incubation $M$. arundinacea caused the best suppression of $R$. microporus growth (Table 2 ). It was assumed that $M$. arundinacea planted in the soil that resulted in the suppression of white root rot incidence was in correlation to the fact that the population of soil fungi was the highest in the rhizozphere of $M$. arundinacea (Figure 1). Root exudates of $M$. arundinacea that apparently contain carbohydrates may enhance the growth of soil fungi and increase their population. It is very likely that the increase of soil fungi population was in line with the increase of the population of antagonistic fungi (Figure 2) and resulted in the suppression of $R$. microporus growth. It is worthy to 
Table 2. Effect of plant root exudates on colony diameter of $R$. microporus

\begin{tabular}{ccc}
\hline \multirow{2}{*}{ Root exudates of } & \multicolumn{3}{c}{ Colony diameter of $R$. microporus } \\
\cline { 2 - 3 } & 3 days & 6 days \\
\hline M. arundinacea & $2.83 \mathrm{ab}$ & $3.58 \mathrm{c}$ \\
S. auranthii & $2.68 \mathrm{~b}$ & $4.98 \mathrm{~b}$ \\
A. galanga & $2.64 \mathrm{~b}$ & $4.72 \mathrm{~b}$ \\
Control & $3.10 \mathrm{a}$ & $6.47 \mathrm{a}$ \\
\hline
\end{tabular}

Numbers in the column followed by the same letter are not significantly different according to LSD test at $\alpha=0.05$.

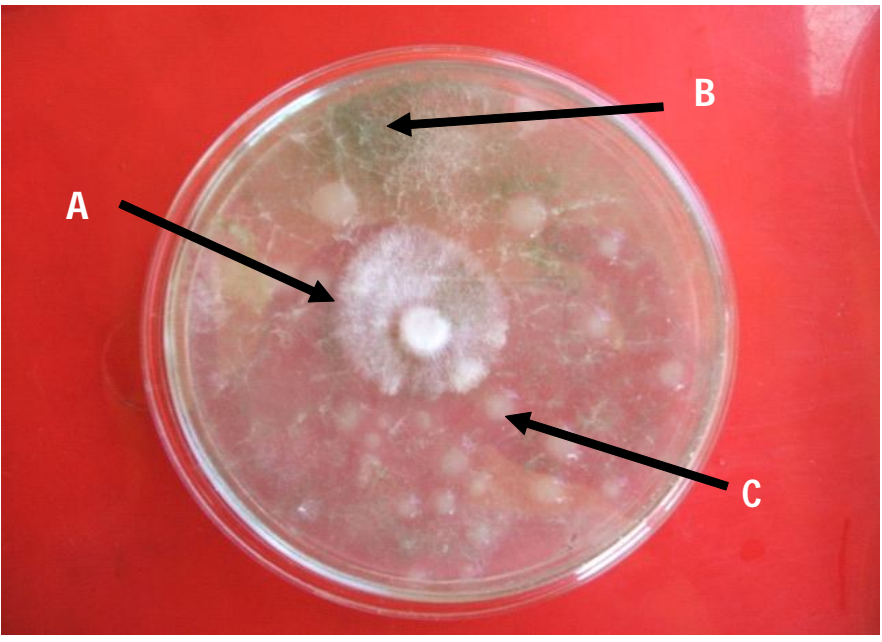

Figure 2. Culture growing on PDA media containing Maranta root exudates. (A) R. microporus, (B) Trichoderma spp., and (C) large colony of yeast.

\section{CONCLUSIONS}

Aplication of natural sulphure, Trichoderma spp. and planting $A$. galanga, S. auranthii and $M$. arundinacea decreased the incidence of white root rot disease in the rubber field. In the laboratory, A. galanga and $S$. auranthii and $M$. arundinacea decreased the colony diameter of $R$. Microporus. In the culture containing exudates of $M$. arundinacea grew Trichoderma spp. and yeast, and the growth of $R$. microporus was suppressed.

\section{ACKNOWLEDGMENT}

We thank to BGBD project in funding this research. We thank to Prof. Dr. FX. Susilo in directing the research and to all our students (Muttaqin, Hanifah Muslimah, Ari Fernando, F. Sari, and Fitri) who join in BGBD research. And we are also in debt to Mr. I Gde Swibawa. especially for his assistance in analysing the data.

\section{REFERENCES}

Azaldin MY. 1985. Control of root diseases of Hevea using sulphur. RRIM Pltr's Bull. 182:9-10.

Basuki. 1981. Penyakit Akar Putih. Berk. Penel. PPPP. Tanjung Morawa. 8.18-33.

Basuki. 1982. Penyakit dan Gangguan pada Tanaman Karet. Pus. Penel. Pengemb. Perkeb. Tanjung Morawa

Basuki. 1986. Pengaruh belerang dalam pengendalian biologis penyakit jamur akar putih pada karet. Konferensi Nasional Karet Medan. 1986. Vol.II. BPP Sei Putih. pp. 413-445.

D’Souza TM, Merritt CS, \& Reddy A. 1999. Lignin modifying enzymes of the white rot basidiomycete Ganoderma lucidum. Appl. Environ. Microbiol. 65(12): 5307-5313. 
Fox RA. 1977. The impact of ecological cultural and biological factors on the strategy and cost of controlling root diseases in tropical plantation crops as exemplified by Hevea brasiliensis. J. Rubb. Res. Inst. Sri Lanka 54 (2):329-362.Fox. R.A. 1966. White root diseases of Hevea brasiliensis. collaprot-ectant dressings. J. Rubb. Res. Inst. Malaya. 19(4):231-241.

Gafur A \& Swibawa IG. 2004. Methods in Nematode and Soil Microbe Research for Belowground Biodiversity Assessment p.117-123 in Conservation and Sustainable Management of Below-Ground Biodiversity in Indonesia. Universitas Lampung. 145pp.

Jayasuriya KE \& Thenakoon BI. 2007. Biological control of Rigidoporus microporus. the cause of white root disease in rubber. Cey. J. Sci. (Bio. Ci.) 36 (1): 9-16.

Martin R \& du Plessix CJ. (1969). White root rot (Leptoporus lignosus) of rubber on Lower Ivory Coast. J. Rubb. Res. Inst. Malaya. 21(1): 96106.

Marziana V. 2008. Uji pengaruh ekstrak dan eksudat tanaman antagonis. Trichoderma spp.. belerang serta urea terhadap pertumbuhan jamur akar putih (Rigidoporus lignosus Swartz: Fr. Van Overeem) secara in vitro. Skripsi. Fakultas Pertanian Universitas Lampung

Monte E. 2001. Understanding Trichoderma: between biotechnology and microbial ecology. Int. Microbiol. 4:1-4.

Lewis JA \& Papavizas GC. 1984. A new approach to stimulate population proliferation of Trichoderma species and other potential biocontrol fungi introduced into natural soils. Phytopathol. 74:1240-1244.

Liyanage AS, Peries OS, Warnapura SS, Senadeera EAT, \& Amaratunga W. 1984. An integrated approach to control of white root diseases in Sri Lanka. Proceeding of the International Rubber Conference Sri Lanka. Vol. 1 (part II). p. 499520.

Prasetyo J, Aeny TN, \& Suharjo R. 2009. The correlation between white rot incidence and physical. chemical. and biological characters of soil in Rubber Ecosystem of Small Holder. J. Tropical Plant Pests and Diseases 9(2): 149-147.
Semangun H. 2000. Penyakit-penyakit Tanaman Perkebunan di Indonesia. Gajah Mada University Press.

Schenk NC \& Perez Y. 1990. Manual for the identification of VA mycorrhizal fungi. Synergistic Publication. Gainesville, Fla.

Situmorang A. 1994. Efektifitas beberapa fungisida yang diaplikasi secara penyiraman terhadap penyakit akar putih (Rigidoporus microspores) pada tanaman karet muda. Prosiding Risalah Seminar Hasil Penelitian. Tahun 1992/1993 Balit Sembawa. Puslit Karet 1994. pp. 95-100.

Situmorang A.1994. Efektifitas biofungisida Trichoderma dalam pengendalian penyakit akar putih (Rigidoporus microporus) pada perkebunan karet Sumatera Selatan dan Jambi. Prosiding Risalah Seminar Hasil Penelitian Tahun 1992/ 1993 Balit Sembawa. Puslit Karet 1994. pp.101107.

Situmorang A. 1996. Pemanfaatan mikroorganisme saprofit pelapuk tunggul karet sebagai alternatif pengendalian penyakit akar putih (Rigidoporus microporus) pada karet. Prosiding Seminar Nasional Mikrobiologi Lingkungan II. Bogor 9-10 Oktober 1996.

Situmorang A \& Budiman A. 1990. Beberapa Metode Aplikasi Fungisida Dalam Pengendalian Penyakit Akar Putih (Rigidoporus microporus) pada Tanaman Karet. Pros. Konf. Nas. Karet. Palembang. Buku II: 383-394.

Situmorang A\& Suryaningtyas H. 2003. Pemanfaatan tumbuhan antagonisme dalam pengendalian penyakit akar putih pada karet. Balai Penelitian Sembawa (belum dipublikasikan). Laporan akhir tahun 2003. pp. 27-40.

Soepena H, Sinulingga W, \& Basuki. 1992. Trichoderma as biolog-ical control agent of white root diseases in rubber plantations. Symposium Integrated Pest Management Control Component Bogor. January 1992. Seameo Biotrop.

Tahia B, Rincon AM, Limon MC, \& Codon AC. 2004. Biocontrol mechanisms of Trichoderma strains. Int. Microbil. 7: 249-260.

Widjanarko S. 1969. Pemberantasan tjendawan akar putih pada karet remadja. Siaran Kilat No. 1 BPP Bogor. Seri Crop Protection. 